\title{
The effect of decoupling on water resources: Insights from European international trade
}

\author{
Ana Serrano $^{\mathrm{a}, *}$, Javier Valbuena ${ }^{\mathrm{b}}$ \\ ${ }^{a}$ Department of Economic Analysis, Faculty of Economics and Business Studies, Universidad de Zaragoza, 50005, Zaragoza, Spain, Instituto Agroalimentario de Aragón \\ (IA2) \\ ${ }^{\mathrm{b}}$ Department of Applied Economics, Faculty of Economics and Business Studies, Universidad de Zaragoza, 50005, Zaragoza, Spain
}

\section{A R T I C L E I N F O}

\section{JEL classification:}

Q25

Q18

Q27

Keywords:

Water

Trade

Decoupling

European union

Common agricultural policy

\begin{abstract}
A B S T R A C T
The concern on the effects and potential consequences of the displacements of water resources through international trade has increased in the last decades. Today, water scarcity is considered one of the main problems in the world. Despite large advances on its quantification and understanding, further research on the anthropogenic determinants of the exchanges of water embodied in international trade is necessary. Our study aims to shed light on the trajectories and explaining factors of water exchanges in the European Union. In particular, we analyse how the 2003 Common Agricultural Policy (CAP) reform, which decoupled direct subsidies from production, affected European water consumption through agri-food exports. First, our methodology relies on the bottom-up approach to estimate European long-term exports of virtual water from 1995 to 2013. Second, we assess the effect of the reform on water consumption using panel data analysis in a trade gravity framework. Our main results show that the 2003 reform boosted extra European virtual water exports. We also observe a large heterogeneity in our sample, pointing to Mediterranean areas as the most affected by the policy reorientation. Spain, one of the most water scarce countries in the European Union, is essential to explain this link.
\end{abstract}

\section{Introduction}

The importance of the agricultural sector in the European Union (EU) has declined as a consequence of the economic progress (Byerlee et al., 2011), accounting for $4.4 \%$ of the total employment in the EU-28 in 2015 , and $1.3 \%$ of the value-added (Okman et al., 2011). Notwithstanding the decline in the relative weight of the primary sector, its economic relevance relative to the EU international trade has increased significantly. The EU has become the main exporter and importer of agricultural and food products in the world since 2010, showing external balance on these goods, mainly as a result of the important upsurge of exports (EUROSTAT, 2018). Besides, the impact of agriculture on the environment and the natural resources is considerable and complex, comprising both positive and negative effects which take place at local, regional, national and global levels (Kampas et al., 2012). Agriculture is widespread across the EU and has caused considerable impacts on land, water, biodiversity and emissions, especially affecting freshwater ecosystems as a large part of Europe's land is dedicated to agricultural uses: $44 \%$ of total water abstracted is for agriculture, while this proportion is higher as far as Southern Europe is concerned, where the ratio reaches 70-80\% (Okman et al., 2011).

Agricultural uses are driven by a variety of macro elements (e.g. socioeconomic and cultural drivers), as well as local factors (Flávio et al., 2017). One of the key macro determinants are agricultural policies, crucial in the development of the primary sector. The EU Common Agricultural Policy (CAP) is a relevant external driver of European agriculture that has had a preeminent role in shaping agricultural production and its consequent environmental impacts (Coderoni and Esposti, 2018). The CAP was introduced in 1962 as a system of guaranteed prices and other programs aiming to support farmers and improve agricultural productivity, and has undergone several changes since then. The MacSharry reform of 1992 was the first step to dismantling market interventions, gradually lowering support prices and introducing coupled direct payments. Then, the 2003 CAP reform (henceforth, 2003 reform) modified the basis of direct support (Phelps, 2007). The 2003 reform represents a significant change in the system of

\footnotetext{
* Corresponding author.

E-mail addresses: asergon@unizar.es (A. Serrano), jvalbuena@unizar.es (J. Valbuena).
} 
farm support provided by two pillars. Based on Pillar 1, direct payments were decoupled from production via the Single Payment Scheme (SPS). The principle of decoupling was established as a cornerstone of the CAP payments, i.e., direct aids were not related any longer to the arable land or animal head, making subsidies to individual farmers independent of the crops grown or the cattle raised in any particular year. To qualify for the payment entitlements, farmers were required to keep agricultural land in Good Environmental and Agricultural Condition (GAEC) and respect relevant Statutory Management Requirements (SMRs) (together referred to as cross-compliance, (Brady et al., 2009)). The former aimed to enhance environmental responsibility and link financial support to compliance with environmental standards. The second pillar concerns rural development policy. The reform promoted the extension of the Rural Development Programme, including the Agri-Environment Programme (AEP) (Stoate et al., 2009), and trying to achieve balanced territorial development as well as promote innovation and competitiveness.

The 2003 reform became mandatory for European member states applying to all direct payments from 2005 onwards, although the full set of requirements established by EU regulation and directives (i.e., SMRs) was not implemented until January 2007 (Jaraitè and Kažukauskas, 2012).

Interestingly, the 2003 reform translated the growing concern on the effects of agricultural activity to the environment. The introduction of decoupling, cross compliance and the extension of the Rural Development Programme were expected to have positive externalities on natural ecosystems (Coderoni and Esposti, 2018). Furthermore, the embodiment of environmental objectives in the 2003 reform do coincide with the implementation of the Water Framework Directive (WFD) that had as its main objective "to ensure access to good quality water in sufficient quantity for all Europeans, and to ensure the good status of all water bodies across Europe" (European Commission, 2000, art. 4).

In this context, our paper aims to assess the role played by the 2003 reform on the trajectories of water exchanged as a result of EU trade from 1995 to 2013. Although there exists recent literature looking at the effects of the CAP on EU trade (Matthews et al., 2017; Matthews and Soldi, 2019), these studies do not consider its environmental consequences. Therefore, this study aims to explore this gap in the research literature by analysing the impact of the decoupling of direct aids on the growing pressures affecting water resources through extra European agri-food exports. Agri-food exports were growing from 1995 to 2013, particularly from 2005 onwards, also entailing the exchanges of natural resources embodied in the goods traded (Schmitz et al., 2012). This was the case of water, a necessary input for the production and trade of agricultural products, that has been recently studied from a global perspective due to the internalization of the economies (Hoekstra and Mekonnen, 2012; Vörösmarty et al., 2015). Thus, given the increasing concern on the effects and potential consequences of the displacements of water resources through international trade, many studies have used the concept of virtual water, i.e., the volume of water necessary for the production of a commodity (Allan, 1993; Allan et al., 1997), to assess the exchanges of water resources as a result of globalization (Carr et al., 2013; Duarte et al., 2016; Tuninetti et al., 2016; Zhao et al., 2015). In this work, we focus on blue virtual water: surface or groundwater evaporated during a production process (Hoekstra et al., 2011). In comparison to green water (water stored in soil as moisture), blue virtual water can be managed and therefore allocated among different uses, showing a higher opportunity cost.

To the best of our knowledge, there is scarce literature on the analysis of the environmental impacts of the 2003 reform (see Brady et al.

\footnotetext{
1 The SPS affected the EU15 members plus Malta and Slovenia. The new member states, that joined from 2004 on, have been incorporated into a progressive system called Single Area Payment Scale (SAPS) (Matthews et al., 2017).
}

(2009) for the effects on landscape and biodiversity, or Coderoni and Esposti (2018) for an ex-post analysis on emissions). According to Volkov and Melnikiene (2017), there is a lack of systematic approaches and instruments to assess the impact of the decoupling system to environmental sustainability. As for water, we can find mostly ex-ante studies at the farm level for the EU-15 (Giannoccaro and Berbel, 2011) and for specific countries (Scardigno and Viaggi (2007) for Mediterranean members, Dos Santos et al. (2010) for Portugal and Kampas et al. (2012) for Greece). Overall, these studies concluded that the focus of the 2003 reform on water issues was limited, and therefore important impacts in terms of water quantity and quality could be induced.

Thus, our paper contributes to the literature on the link between water impacts and the 2003 reform from different perspectives. First, it offers a macro and ex-post (based on real data) assessment of one of the main drivers of global water displacements, the agricultural policy. Quantifying the actual environmental effects of agricultural policy reforms is particularly relevant, especially with the perspective of the debate on the post-2020 CAP scheme. The reform proposal has nine main objectives, three of them with a clear environmental focus: climate change action, environmental care and preserve landscapes and biodiversity (European Commission, 2018). Second, the sample considered, including 290 products and 222 countries (with 28 member states), is one of the strengths of the study. This high level of disaggregation at the product level allows further analysis in the explanation of water exports by accounting for the potential heterogeneity of the effect of the reform on different products, as well as preventing the aggregation bias associated to the relative prices of different goods. Third, the long-term perspective is essential to evaluate the historical changes driven by the 2003 reform in a period of trade expansion. Finally, the methodological approach, which combines a bottom-up focus with panel fixed effects regressions, allows us to exploit the longitudinal dimension of our highly disaggregated data, as well as accounting for potential endogeneity issues associated to our gravity-equation specification.

The rest of the paper is organised as follows. Section 2 explains the methods and data used. First, in section 2.1 the bottom-up calculation of our variable of interest is explained. Then, in section 2.2 we discuss the econometric specification and estimation strategy. In section 3 we present the results. Section 3.1 shows the descriptive evidence on the water embodied in extra European exports as well as the main findings on the impact of the 2003 reform. Section 3.2 focuses on the analyses of the heterogeneous effects of the reform. The paper closes with the main conclusions and a discussion in Section 4.

\section{Methods and data}

\subsection{Calculation of virtual water exports}

First, we calculate the blue water embodied in extra European bilateral exports according to the method proposed by Hoekstra and Hung (2005). Given a country $i$ in year $t$, the virtual water exports (VWX) to country $j$ for each agri-food product $p\left(V W X_{\text {cipt }}\right)$ are:

$V W X_{i j p t}=w_{i p} * x_{i j p t}$

Being $x_{i j p t}$ the volumetric quantity of product $p$ exported by country $i$ to $j$ in year $t$ expressed in tonnes, and $w_{i p}$ the product blue water footprint that measures the volume of blue water necessary to produce a tonne of each commodity in the exporting country.

Bilateral trade data on agricultural and food products $\left(x_{i j p t}\right)$ are from United Nations Statistics Division (United Nations, 2019) at the four-digit level of the Standard International Trade Classification, SITC, revision 3. We use annual trade data from 1995 to 2013 to be able to capture the trends on VWX before and after the 2003 reform. Our sample considers 290 products and 222 countries (28 EU and 194 non-European 
countries), ${ }^{2}$ accounting for approximately $85 \%$ of agricultural and food commercial exchanges in the world during these years. Finally, the product water footprints $\left(w_{i p}\right)$ stem from Mekonnen and Hoekstra (2012, 2011). These water footprint coefficients, expressed in $\mathrm{m}^{3}$ /tonne, inform on the volume of water necessary to produce a tonne of each agricultural commodity in each producing country.

\subsection{Econometric specification and estimation strategy}

As the next step, we present the trade gravity model that will be the main tool used to evaluate the impact of the 2003 reform on VWX. From the seminal work of Tinbergen (1962), the gravity equation of trade has become one of the main methodological approaches adopted to assess the main determinants of bilateral trade flows (Anderson, 1979; Anderson and van Wincoop, 2003; Bergstrand, 1989; 1985; Eaton and Kortum, 2002; Head and Mayer, 2014). Recently, this framework has been increasingly employed to evaluate the environmental impacts generated by international trade, namely carbon emissions (Aichele and Felbermayr, 2015; Duarte et al., 2018; Frankel and Rose, 2005) and water (Duarte et al., 2019). In this paper, we apply an econometric panel data model that allows studying European VWX with a temporal dimension. In this regard, the long-term perspective is essential to capture relevant historical moments affecting trade patterns and water consumption. First, the agreement on agriculture initiated in the Uruguay Round of the General Agreement on Tariffs and Trade (GATT) in 1992, entered into force in 1995 with the beginning of the World Trade Organization (WTO). It involved specific commitments to reduce domestic support and export subsidies and therefore an intensive liberalization of agricultural trade and the extension of globalization to primary markets. In this context, the 2003 reform changed the orientation of direct aids trying to support income while minimizing market distortions. During these years, a considerable enlargement of the European Union also happened and the WFD was implemented.

First, we estimate the effect of the policy reform using the gravity model standard in the literature. Our baseline specification is as follows:

$$
\begin{aligned}
& V W X_{i j p t}=\beta_{0}+\beta_{1} \operatorname{Cou}_{i t} \text { inter }_{i j t}+\beta_{2} \mathrm{RD}_{i t} \text { inter }_{i j t}+\beta_{3} \boldsymbol{X}++u_{i j p t} \\
& \text { Cou }_{i t}=\frac{\text { Coupled aids }_{i t}}{\text { Total direct aids }} \text { it }
\end{aligned}
$$

Where $V W X_{i j p t}$ are European blue VWX from country $i$ to $j$ of product $p$ in year $t$. As we show in Eq. (3) $\mathrm{Cou}_{i t}$, our main variable of interest, is the share of coupled aids on total direct payments (coupled plus decoupled aids). It reflects the main change of the 2003 reform, i.e., the transition from coupling to a decoupling regime. To sharpen the identification, we also include $\mathrm{RD}_{i t}$, i.e., the rural development subsidies of the Pillar 2 introduced by the reform. The data for the $\mathrm{Cou}_{i t}$ and $\mathrm{RD}_{i t}$ variables is drawn from Farm Accountancy Data Network (2018). Notice that $\mathrm{Cou}_{i t}$ and $\mathrm{RD}_{i t}$ are interacted with inter ${ }_{i j t}$, a dummy variable that takes the value 1 if the bilateral trade flow is extra European in year $t$ and 0 if trade is between EU countries. $\boldsymbol{X}$ is a vector that contains the traditional variables included in trade gravity models. More concretely, we include population (POP) and Gross Domestic Product (GDP) of both commercial partners (in logarithms) by means of controlling for the scale of the countries (World Bank, 2019). In this specification, we also use DISTANCE (in logarithms) as a proxy for trade costs. Additionally, we include dummies that control for the effect of having a common border (CONTIGUITY), a common currency (CURRENCY), a colonial past (COLONY), a common religion (RELIGION), or a common language (LANGUAGE). All these variables come from Mayer and Zignago (2011). Notably, trade agreements also influence international trade and VWX.

\footnotetext{
${ }^{2}$ Note that the countries are considered as EU members after its accession date.
}

Thus, we use dummies that take the value 1 if the importer country belongs to the WTO. ${ }^{3}$ Finally, we include a dummy variable that indicates whether both partners participate in the same regional trade agreement (RTA). These data were taken from Head et al. (2010) and Head and Mayer (2014). ${ }^{4} u_{i j p t}$ represents the idiosyncratic error term.

It is important to note that we are using highly disaggregated data, in particular for the measurement of VWX. Therefore, we are able to carry out the analysis of VWX at the product level, accounting for the potential heterogeneity of the effect of the 2003 reform on different products. Furthermore, it also allows us to exploit the fact that the relative prices of particular goods may affect VWX differently, thus preventing the aggregation bias present in the studies using aggregate bilateral data.

Regarding the empirical approximation, the standard gravity model regressions estimated using ordinary lest squares (OLS) imply that all observations for which there is no trade will be lost when taking logarithms, with the consequent loss of relevant information. In addition, this model also suffers from heteroskedasticity (Santos-Silva and Tenreyro, 2006, 2010). Therefore, following recent lines of discussion in the economic literature (Head and Mayer, 2014; Yotov et al., 2016), we use the Poisson Pseudo-Maximum Likelihood (PPML) estimator. This approach has become standard to obtain trade gravity estimates as it is robust to heteroskedasticity and avoids the problem of zero values in bilateral trade data (Santos-Silva and Tenreyro, 2006, 2010).

Moreover, the estimated coefficients might be biased due to endogeneity issues as the traditional gravity models depicted in Eq. (2) do not consider either the importance of relative trade costs in determining trade flows (omitted variable bias), or unobservable bilateral trade costs and the potential selection of countries into trade associate to policy reforms (selection bias). Multilateral resistance terms (MRT) capture the fact that any country ( $i$ or $j$ ) face trade barriers with all its trade partners. Thus, including MRT avoids generating biased estimates as a result of the omission of relevant variables (Anderson and van Wincoop, 2003; Anderson and Valenzuela, 2008). Following Baier and Bergstrand (2007) and Egger and Nelson (2011) we will include exporter-product and importer-product-time fixed effects to control for MRT. This will essentially "purge" the 2003 reform effects of omitted variable bias caused by multilateral characteristics not connected to the reform. On the other hand, countries likely select endogenously into trade based on observable characteristics, possibly correlated with the level of trade (Baier and Bergstrand, 2004). Moreover, the error term of the gravity model might contain unobservable domestic policies and other bilateral barriers affecting trade that could also be related to the policy reform. Thus, the potential correlation between the 2003 reform and the gravity equation error term suggests that the coefficient associated to the reform will tend to be biased. Therefore, we use bilateral pair-product fixed effects to correct for these sources of bias (Baier and Bergstrand, 2007).

In this context, trying to mitigate the aforementioned problems associated to the standard gravity model, and to further evaluate the impact of the main changes induced by the 2003 reform on extra European $\mathrm{VWX}$, we use the following specification:

$V W X_{i j p t}=\beta_{1} \operatorname{Cou}_{i t}$ inter $_{i j t}+\beta_{2} \mathrm{RD}_{i t}$ inter $_{i j t}+\alpha_{i p t}+\alpha_{j p t}+\delta_{i j p}+u_{i j p t}$

Where $V W X_{i j p t}$ are European virtual water exports from $i$ to $j$ of product $p$ in year $t . \alpha_{i p t}$ and $\alpha_{j p t}$ are the exporter-product and importer-producttime fixed effects controlling for time varying unobserved multilateral heterogeneity of exporting and importing countries, i.e., MRT (Baier and Bergstrand, 2007; Egger and Nelson, 2011). $\delta_{i j p}$ are pairwise-product fixed effects (Baier and Bergstrand, 2007), which capture all

\footnotetext{
${ }^{3}$ Note that inclusion of an exporter dummy is infeasible as all European countries do belong to the WTO; therefore, it would perfectly predict exporter trade flows.

4 Table A1 in the supplementary information shows the descriptive statistics of the main variables used in the analysis.
} 
unobserved time invariant factors that might otherwise be picked up by $\mathrm{Cou}_{i t}$, our variable of interest. Egger and Nigai (2015) also show that using exporter and importer-time fixed effects in conjunction with pair fixed effects is consistent with general equilibrium conditions, and that account for bilateral trade costs and country specific characteristics better than the traditional gravity variables. The dummies controlling for MRT are perfectly collinear and absorb the effect of any country-time variable as $\mathrm{Cou}_{i t}$ and $\mathrm{RD}_{i t}$. Then, in order to be able to control for MRT while estimating the effect of these exporter and importer-time variables, Beverelli et al. (2018) and Heid et al. (2017) propose estimating the model with international and intra-national trade flows and interact the variables of interest with an indicator of international trade flows $\left(\right.$ inter $\left._{i j t}\right)$. In our particular case, as we are interested in the main effect of the policy reform (measured using $\mathrm{Cou}_{i t}$ ) concerning extra-European VWX, we estimate the model with intra and extra European trade flows and the indicator inter $r_{i j t}$ selects only extra-European exchanges. Thus, capturing the time-varying effect of the reform on extra-European trade flows relative to intra-European exchanges.

Finally, although the exporter-product and importer-product-year dummies control for endogenous prices, especially when we are running the regressions at the product level, there may exist trends over time in the effects of unobserved bilateral heterogeneity, such as changes in bilateral prices. Alternatively, following Bergstrand et al. (2015) we estimate Eq. (5), where $\delta_{i j p}{ }^{*}$ Trend are the country pair-product fixed effects interacted with a time trend, which allow for time variation in unobserved heterogeneity across pairs (i.e., bilateral prices).

$V W X_{i j p t}=\beta_{1} \operatorname{Cou}_{i t}$ inter $_{i j t}+\beta_{2} \mathrm{RD}_{i t}$ inter $_{i j t}+\alpha_{i p t}+\alpha_{j p t}+\left(\delta_{i j p} *\right.$ Trend $)+u_{i j p t}$

Hence, we are confident that our empirical model isolates an unbiased direct effect of the 2003 reform, as measured by $\mathrm{Cou}_{i t}$, on VWX.

\section{Results}

\subsection{The 2003 reform as a driver of the increase in $V W X$}

On average, water embodied in extra European exports (blue solid line in Fig. 1) increased at 3.1\% every year between 1995 and 2013. Despite the strength of the Euro, and the enlargement of the EU that entailed a considerable rise of agricultural imports, European agri-food exports notably grew during these years, involving higher pressures on domestic water resources. Looking at Fig. 1 we observe that, although with some annual fluctuations, this growth was fairly flat until 2007. In fact, average extra European VWX during the period 1995-1997 were very similar to those between 2006 and 2008. The picture is very different from 2007. VWX boosted growing at $12 \%$ yearly during the

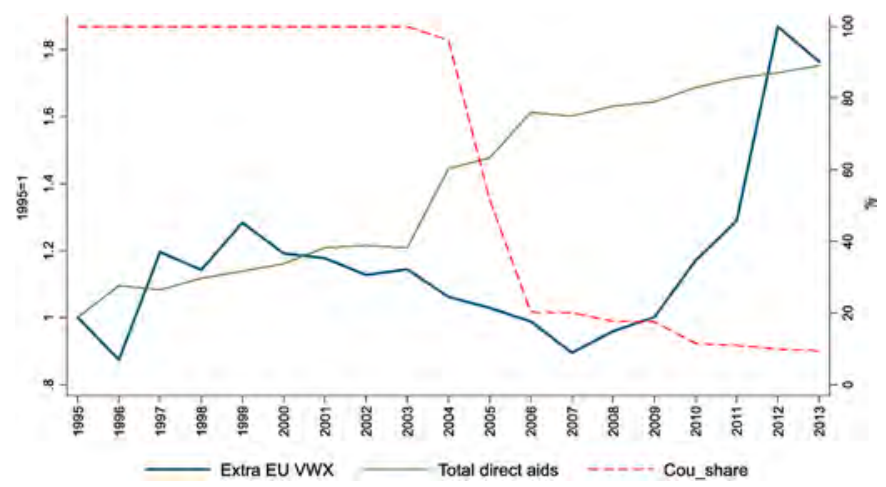

Fig. 1. Extra European blue VWX and total direct aids (index $1995=1$, left axis) and share of coupled subsidies on direct aids (\%, right axis). (For interpretation of the references to colour in this figure legend, the reader is referred to the Web version of this article.) period 2007-2013. This expansion of agri-food exports was particularly significant in a context of global economic crisis, and commercial restrictions with some of the main traditional trade partners as Ukraine and Russia (European Commission, 2016). At this point, it is important to consider that although agri-food exports represent around 7\% of total European exports (European Commission, 2016), considering virtual water this figure reaches $22 \%$, being especially high in some southern countries as Spain, where it accounts for more than $50 \%$ (Serrano et al., 2016).

Fig. 1 also shows that total direct aids (green solid line) continuously increased between 1995 and 2013, growing at 3.2\% yearly on average. As explained in the introduction, the 2003 reform changed the way that the EU supports the agricultural sector by removing progressively direct payments coupled to production (Pillar 1). That is, the 2003 reform completely overhauled the composition of direct payments, substituting coupled for decoupled aids from 2003 onwards. In particular, whereas direct aids were $100 \%$ coupled with production until 2003, the ratio of coupled to total direct aids (our variable of interest defined in Eq. (3)) fell sharply up to $50 \%$ in $2005,{ }^{5} 20 \%$ in 2007 and kept decreasing reaching $9 \%$ in 2013 (Fig. 1). At the same time, decoupled payments experienced a 29-fold increase between 2004 and 2013. ${ }^{6}$ That is, the vast growth in VWX concurs with a significant reorientation of the CAP that crystalized with the 2003 reform (Jaime et al., 2016; Jaraite and Kažukauskas, 2012).

During these years there was also a significant increase in rural development subsidies (Pillar 2) that were however lower compared to direct aids (either coupled o decoupled). According to the Farm Accountancy Data Network (2018) data, Pillar 2 subsidies were approximately $23 \%$ of Pillar 1 aids in 2013. From an economic viewpoint, the 2003 reform increased the competitiveness of the agri-food sectors (European Commission, 2007), reducing the distortions introduced by coupled subsidies and fostering market signals in a context of increasing globalisation (Garrido et al., 2010). After this first descriptive approximation, we observe that the 2003 reform coincides with a substantial increase in extra European agri-food trade, thus potentially intensifying the pressures on water resources. Therefore, we now proceed to evaluate this hypothesis.

The gravity model depicted in Eq. (4) aims to explain the variation in country pairs' water trade flows in terms of the countries' characteristics in the presence of the 2003 reform. At this point, it is important to recall that we are estimating our results at the product level, thus controlling for potential changes in the world price of water-intensive products over the time period of the reform, which may have affected trade patterns (i. e., aggregation bias). Table 1 summarises the findings of the policy impact on the countries' variation in VWX. Columns (1) and (2) show the OLS and PPML estimates respectively, both without fixed effects. Estimation results indicate a positive association between the 2003 reform and VWX, suggesting that the policy has contributed to the reduction of the total water embodied in EU exports. Notice that our policy measure, $\mathrm{Cou}_{i t}$, is defined as the (decreasing) share of coupled subsides over total direct payments, and therefore, a positive coefficient would indicate that a reduction in the relative importance of coupled payments decreases VWX. PPML estimation improves OLS coefficients by considering all information available as well as heteroskedasticity. However, we are aware of the necessity to address other sources of bias associated to endogeneity issues. First, as explained in the methodology, we need to consider MRT by including exporter-product and importer-

\footnotetext{
5 Recall that the 2003 reform was mandatory for all EU member states since 2005.

${ }^{6}$ Notice that several EU countries had already implemented some crosscompliance measures before 2005, following the optional Horizontal Regulation in the CAP reform of 1999 (Article 3 in European Commission (1999)). See Bergschmidt et al. (2003) for a discussion on the different national cross-compliance measures introduced across EU countries.
} 
Table 1

Estimation results of the 2003 reform, 1995-2013.

\begin{tabular}{|c|c|c|c|c|c|}
\hline & \multirow{2}{*}{$\frac{(1)}{\text { OLS }}$} & \multirow{2}{*}{$\frac{(2)}{\text { PPML }}$} & \multirow{2}{*}{$\frac{(3)}{\text { PPML MRT }}$} & \multirow{2}{*}{$\frac{(4)}{\text { PPML MRT Pair }}$} & \multirow{2}{*}{$\frac{(5)}{\text { PPML MRT Pair-Trend }}$} \\
\hline & & & & & \\
\hline \multirow[t]{2}{*}{ Cou (coupled share) } & $0.907 * * *$ & $0.461^{* * *}$ & $-0.468^{*}$ & -0.0723 & -0.0720 \\
\hline & $(0.0233)$ & $(0.152)$ & $(0.245)$ & $(0.0562)$ & $(0.0562)$ \\
\hline Observations & 911,290 & $1,566,864$ & 819,614 & 780,311 & 780,311 \\
\hline R-squared & 0.0926 & 0.193 & 0.924 & 0.990 & 0.990 \\
\hline Exporter-product-time FE & NO & NO & YES & YES & YES \\
\hline Importer-product-time $\mathrm{FE}$ & NO & NO & YES & YES & YES \\
\hline Pair-product FE & NO & NO & NO & YES & NO \\
\hline Pair-product-trend FE & NO & NO & NO & NO & YES \\
\hline
\end{tabular}

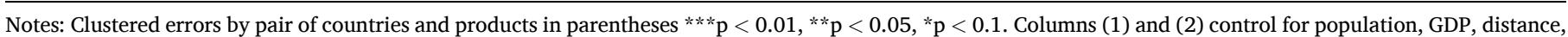
colonial past, common language, contiguity, common currency, WTO belonging, RTA and rural development subsidies.

product-time fixed effects in order to mitigate endogeneity coming from omitted variable bias. Secondly, we need to address the bias associated to unobservable bilateral trade costs and the potential selection of countries into trade. We then proceed to include the corresponding pairwise fixed effects to tackle the endogeneity affecting trade.

Thus, Table 1 also shows the estimates once we have accounted for the omitted variable bias by adding exporter-product and importerproduct-time fixed effects (column 3). As a result, it turns out that the link between the (declining) share of coupled aids and water embodied in exports is inverse, although marginally significant, indicating that the 2003 reform triggered an increase in VWX. However, there is no indication of any effect of the 2003 reform when unobserved time invariant heterogeneity and selection bias are added to the model by including pair fixed effects (column 4). Additionally, we also re-estimate our results based upon Eq. (5), which includes country pair-product fixed effects interacted with a time trend. ${ }^{7}$ This specification allows for a trend change in the effect of the pair fixed effects, such as variations in bilateral prices over time that might be influencing trade. Column (5) reports the results using Eq. (5), which are directly comparable to those in column (4). It is clear that there is not much difference in the estimated effect using equation specifications (4) or (5). Consequently, for the remainder of the analysis we focus on Eq. (4) as our preferred specification. $^{8}$

\subsection{Heterogeneous effects of the 2003 reform}

The main concern associated with the average estimates presented in Table 1 is that there may still hide substantial heterogeneity of the 2003 reform effects on VWX along time and across EU regions.

First, we consider the policy timing as a source of heterogeneity on the decoupling effect. EU countries had certain control regarding the domestic implementation of the 2003 reform. Some of them had already included different cross-compliance measures in their national legislation before 2005 (Bergschmidt et al., 2003). As we explained in the introduction, the decoupling of direct aids was compulsory from 2005, although the complete set of cross-compliance measures became mandatory for all EU countries in January 2007. Thus, in order to exploit the effect of the 2003 reform we need to consider the time span associated to its full implementation.

In Table 2 we explore the role of the policy timing. Columns (1) and (2) depict the estimates when we restrict the sample to the time when the 2003 reform was mandatory (2005-2013) and fully implemented (2007-2013), respectively. Both effects are now negative and

\footnotetext{
${ }^{7}$ Note that the inclusion of $i j$ fixed effects interacted with time dummies is not possible as it would perfectly predict trade flows.

8 Eq. (4) is the preferred specification since it uses the PPML as recommended by literature on trade gravity (Head and Mayer, 2015; Yotov et al., 2016), accounts for omitted variable bias, unobserved heterogeneity and potential selection effects.
}

statistically highly significant, which points at the decoupling of direct aids as a determinant of VWX growth. The result in column (2) is more than 2.7 times as large compared to the estimation in column (1), indicating that once the 2003 reform was completely carried out, the impact on VWX was higher. Concretely, from 2007, a $1 \%$ fall in the share of coupled aids results in $0.64 \%$ increase in water embodied in extra EU exports relative to intra EU trade flows (column 2 in Table 2).

Thus, our panel data estimations confirm the hypothesis that decoupling was a significant driver for the growing impacts on European water resources as a result of the internationalization of the agri-food sector. This result is consistent with the previous literature. Scardigno and Viaggi (2007) warned that despite the safeguard of the environment was one of the main objectives of the 2003 reform, sustainable water management was not among the main goals of the CAP entailing impacts on the quantity and quality of water resources. Llamas et al. (2012) state that the CAP affects global food trade and virtual water exchanges. Similarly, Kampas et al. (2012) found that decoupling may lead to higher water demand under low water prices since it induces the expansion of irrigated crops. ${ }^{9}$ Chico and Garrido (2012) acknowledge that given the increasing link between international markets and water, the need to balance the market forces with the available local resources is becoming increasingly important. Finally, Collantes (2020) recognizes that the environmental balance of the CAP has been pretty poor, despite the curbing of land abandonment and fertilizers use.

The second source of heterogeneity would be related to the regional divergences across the EU. The empirical evidence available has shown that the environmental outcomes associated to decoupling in the EU greatly depend on regional socio-economic and climatic characteristics (Brady et al., 2009). Looking at VWX, the growing pressures on water resources were not homogeneous across countries. Fig. 2 shows that

Table 2

Heterogeneous effects of the 2003 reform considering the timing of policy implementation.

\begin{tabular}{|c|c|c|}
\hline & (1) & (2) \\
\hline & $2005-2013$ & 2007-2013 \\
\hline Coupled share & $\begin{array}{l}-0.235^{* * *} \\
(0.0766)\end{array}$ & $\begin{array}{l}-0.637^{* * *} \\
(0.229)\end{array}$ \\
\hline Observations & 465,334 & 371,955 \\
\hline R-squared & 0.993 & 0.994 \\
\hline Exporter-product-time FE & YES & YES \\
\hline Importer-product-time FE & YES & YES \\
\hline Pair-product FE & YES & YES \\
\hline
\end{tabular}

Notes: Clustered errors by pair of countries and products in parentheses $* * * \mathrm{p}<$ $0.01, * * \mathrm{p}<0.05,{ }^{*} \mathrm{p}<0.1$.

\footnotetext{
9 This study uses a nonlinear optimization model and only focuses on a specific region (Thessaly, Greece).
} 


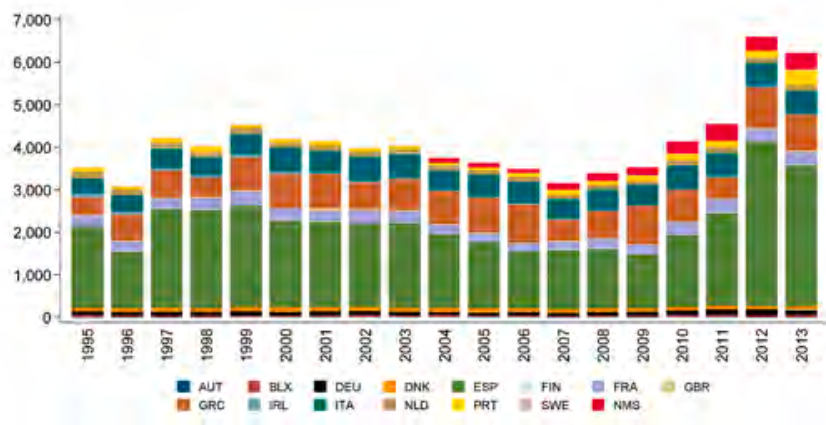

Fig. 2. Country composition of extra European blue VWX (million cubic meters), 1995-2013. Note on country codes: AUT: Austria, BLX: Belgium and Luxembourg, DEU: Germany, DNK: Denmark, ESP: Spain, FIN: Finland, FRA: France, GBR: Great Britain, GRC: Greece, IRL: Ireland, ITA: Italy, NLD: Netherlands, PRT: Portugal, SWE: Sweden, NMS: New member states. (For interpretation of the references to colour in this figure legend, the reader is referred to the Web version of this article.)

Mediterranean areas (Spain, France, Greece, Italy and Portugal), which on average weighted over 86\% on European blue VWX from 1995 to 2013 , were the most affected by the expansion of agri-food exports. If the VWX kept quite stable in Mediterranean countries until 2007, it soared increasing at $11.8 \%$ yearly between 2007 and 2013 , which nearly replicates the growth found for the whole sample. Besides, from 2004 to 2013 thirteen new member states (NMS in Fig. 2) incorporated to the CAP. These countries, with a larger share of agriculture in their economic structure as compared to EU-15 areas, represented only $6.6 \%$ of the total European blue VWX on average, and triggered $9 \%$ of the growth in VWX between 2007 and 2013.

The regional patterns of VWX are closely associated to the product composition of these flows ${ }^{10}$. Fig. 3 shows that vegetable oils, textile fibres, meat, vegetables and fruits, and cereals were on average the most significant commodity groups in blue VWX. From the mid-nineties to 2007, cereals, vegetables oils and sugars depict decreasing shares, whereas textile fibres and leather show growing weights. Then, from 2007 to 2013 VWX increased mainly as a result of vegetable oils exports,

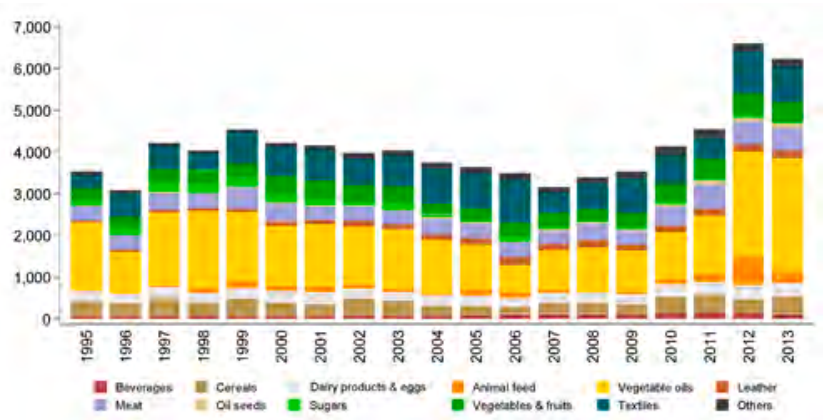

Fig. 3. Product composition of extra European blue VWX (m3). (For interpretation of the references to colour in this figure legend, the reader is referred to the Web version of this article.)

\footnotetext{
${ }^{10}$ As explained in the methodology, agri-food exports are measured considering the water used for its production (virtual water), and therefore the findings in terms of product composition of VWX can differ to those of monetary exports. In this regard, Garrido et al. (2010) show that despite wine and olive oil displaying the same monetary value of exports in Spain, the olive's virtual water is much larger than that of grapes, and therefore the VWX of olive oil could be up to 30 times larger compare to wine.
}

which accounted for $54 \%$ of the total growth. Animal feed also increased its importance in blue VWX, going from $2 \%$ on total VWX in 2007 to $7 \%$ in 2013. Meat, vegetables and fruits together with cereals, drove the increase in blue VWX after 2007, although their shares remained stable. Finally, textile fibres lost weight, reaching a share similar to that of the mid-nineties.

Thus, looking at the country and crop patterns of VWX, and comparing the results of the PPML with exporter-product and importerproduct-time fixed effects, and pairwise-product fixed effects (columns 3 and 4 in Table 1) to the corresponding OLS and PPML without fixed effects (columns 1 and 2 in Table 1), we observe that the effect of the 2003 reform on VWX is likely to be highly heterogeneous across EU regions. Then, given the regional heterogeneity in VWX and the predominance of the Mediterranean area as an exporter of virtual water, we further analyse the extent to which the decoupling effect is associated to country characteristics by assessing only Mediterranean countries.

Columns (1) and (2) in Table 3 display the estimations associated only to Mediterranean countries for the periods 2005-2013 and 2007-2013, respectively. When considering the mandate of the policy (2005-2013), the size of the 2003 reform effect increases by about 1.31 times compared to the estimation that include all EU countries (column (1) in Table 2), and is also statistically significant. We repeat this exercise considering the full implementation of the policy in Mediterranean countries (2007-2013) in column (2). From 2007, a 1\% fall in the share of coupled aids implies a $1.12 \%$ increase in VWX for Mediterranean countries. We observe how the estimate increases substantially. In particular, it is 1.8 times larger relative to the complete accomplishment of decoupling in the EU (column 2 in Table 2) and 3.6 times higher compared to the period 2005-2013 in Mediterranean countries (column 1 in Table 3). This is an indication that Mediterranean areas are responsible for most of the policy effect, particularly after the full implementation of the 2003 reform (2007-2013). Most Mediterranean countries (Spain, France, Greece, Italy and Portugal) opted for an "historical SPS"11 that used as a reference the period 2000-2002. As a result, the distribution of decoupled payments among farmers was based on the "old" coupled subsidies differentiated by products, and remained virtually unchanged after the 2003 reform. Nevertheless, these aids were no longer tied to the production of a certain good, and farmers could choose to produce high valued agricultural commodities with a growing demand in global markets. This includes, for example, the Mediterranean olive oil.

As Stoate et al. (2009) warned, the effect of decoupling seems to have very different impacts, particularly associated to regions already characterised by being intensive in agriculture. These differences across regions tend to escalate along with international trade and competition as the (increasing) production of the most valuable crops is region specific, leading to potentially damaging effects on water resources (Chico and Garrido, 2012). Concretely, international markets have been increasingly demanding Mediterranean products as olive oil and wine, and high value-added crops, mostly fruits and vegetables. This entailed important agricultural transitions as the conversion of arable land into permanent crops and the intensive agricultural production of many of these goods, oriented to foreign markets (Stoate et al., 2009). Southern European regions have good climatic conditions to grow these agricultural products, but are also characterised as water scarce countries, being irrigation essential for this specific agricultural production. In this regard, the European Environment Agency (2018) shows that irrigation is the main pressure on water resources in the Mediterranean region reaching around $80 \%$ of the total net water use, with an irrigated area that has

\footnotetext{
11 The SPS had three implementation schemes. The regional model that granted and equal entitlement per hectare in a region, the historical model with differentiated payments per farm based on the subsidies received in the period 2000-2002, and the hybrid model that is a combination of historical and regional models.
} 
Table 3

Regional Heterogeneity in the effects of the 2003 reform.

\begin{tabular}{|c|c|c|c|c|}
\hline & (1) & (2) & (3) & (4) \\
\hline & $\begin{array}{l}\text { MED } \\
2005-2013\end{array}$ & $\begin{array}{l}\text { MED } \\
2007-2013\end{array}$ & $\begin{array}{l}\text { MED: No } \\
\text { Spain } \\
\text { 2005-2013 }\end{array}$ & $\begin{array}{l}\text { MED: No } \\
\text { Spain } \\
2007-2013\end{array}$ \\
\hline Coupled share & $\begin{array}{l}-0.309^{* *} \\
(0.137)\end{array}$ & $\begin{array}{l}-1.122^{* * *} \\
(0.346)\end{array}$ & $\begin{array}{l}0.00180 \\
(0.105)\end{array}$ & $\begin{array}{l}-0.703 \\
(0.482)\end{array}$ \\
\hline Observations & 156,698 & 123,979 & 99,922 & 79,294 \\
\hline R-squared & 0.995 & 0.996 & 0.994 & 0.995 \\
\hline $\begin{array}{l}\text { Exporter-product- } \\
\text { time FE }\end{array}$ & YES & YES & YES & YES \\
\hline $\begin{array}{l}\text { Importer-product- } \\
\text { time FE }\end{array}$ & YES & YES & YES & YES \\
\hline Pair-product FE & YES & YES & YES & YES \\
\hline
\end{tabular}

Notes: Clustered errors by pair of countries and products in parentheses $* * * \mathrm{p}<$ $0.01, * * \mathrm{p}<0.05, * \mathrm{p}<0.1$.

increased by $12 \%$ from 2002 given the growth in utilised crop areas. Thus, the 2003 reform encouraged the intensive production and exports of high valued and irrigated agricultural commodities, boosting the use of water resources, even in a context of technological innovations that increased the efficiency of irrigation systems.

Within the European Mediterranean area, the largest impact on water resources happened in Spain (see Fig. 2, in green). On average, Spanish VWX were around $50 \%$ on total European VWX and represented more than 70\% of the total increase in European VWX occurred from 2007. Spanish agri-food exports are high valued and water-intensive ${ }^{12}$ goods like fruits, vegetables, olive oil and wine, which are adapted to the Mediterranean climate and depend on water from irrigation (Duarte et al., 2016; Garrido et al., 2010). Irrigation in Spain represents $60 \%$ of agricultural production and $80 \%$ of farmers' exports. This figure is striking, especially considering that Spain is the most water scarce country in the EU, after Malta and Cyprus, with a Water Exploitation Index (WEI) of 33\% in 2012 (Okman et al., 2011). Despite its relevant role for the development of the Spanish agricultural system, the economic, social and environmental sustainability of irrigation infrastructures has been questioned (Cazcarro et al, 2015, 2019).

In this context, trying to highlight the importance of a single country (Spain) driving the results on VWX, even after considering the full implementation of the 2003 reform, columns (3) and (4) in Table 3 show the corresponding estimates when Spain is excluded from the sample. It is certainly clear from the results that the effects of the policy reform are completely driven by Spain. The estimate associated to the period 2005-2013 in column (3) has turned positive and lost all statistical significance. Besides, looking at column (4) in Table 3 where the policy is evaluated after it has been fully implemented (2007-2013), we observe that there still exists a negative link between the share of coupled aids and VWX but it is not significant. We interpret this finding as an indication that most of the scale and composition changes originated as a result of the policy reform took place in Spain.

In this regard, Ruiz et al. (2011), suggest that the reform involved the redistribution of land in Spain, being the profitability of crops an important criterion for this change. Similarly, Garrido and Varela-Ortega (2008) found gradual and steady variations in the composition of irrigated land in Spain since the 2003 reform. For example, they observed that between 2004 and 2006 the irrigated area decreased for maize, legumes, rice, sugar beet and cotton, products that benefited from subsidies before the reform but that experienced an important decoupling. On the contrary, the irrigated surface increased for vineyards and olive trees, which more than doubled between 1995

\footnotetext{
12 See Tables A2 and A3 in the SI with information of the water intensity of products.
}

and 2008 (Chico and Garrido, 2012). Between 2008 and 2013 the ratio of irrigated on total surface moved from $29.2 \%$ to $35.4 \%$ in the case of vineyards and from $25.7 \%$ to $28.6 \%$ for olive trees (MAPA, 2013, 2008). This trend is quite significant, given the importance of vineyards and olive trees in 2013 , which occupied $21 \%$ and $10 \%$ of total crop area, respectively (MAPA, 2013). Therefore, the 2003 reform reduced the incentives of producing certain water-intensive crops. However, the policy reform intensified the spatial concentration of irrigated production and exports in some regional specific crops -mainly Andalusia for olive trees and vegetables and Castile La Mancha for wine (Martín-Retortillo et al., 2020). For the specific case of olive trees, the expansion of the Spanish production and trade was historically associated to the extension and intensification of olive farming, closely linked to irrigation and to landscapes transformation that changed into an olive monoculture (Scheidel and Krausmann, 2011). Then, the decoupling of payments between 2006 and 2013 (based on the average aids received in the reference period 1999-2002) reinforced this long term process (De Graaff et al., 2011). These product compositional patterns coincide with an ambitious plan for irrigation modernization led by the Spanish government in the last decade. Notwithstanding the conversion of surface into drip irrigation systems, the increase in irrigated area and some crop changes could have involved higher water consumption (Llamas et al., 2012).

In light of this, the main changes in crop production alongside with the specialization and improvement of the Spanish terms of trade in specific agricultural irrigated products (olive oil, wine, vegetables and fruits) increased the consumption of blue water resources in Spain (Chico and Garrido, 2012), offering support for the results observed in Table 3.

\section{Conclusions}

The 2003 reform entailed a deep reorientation of the EU agricultural policy, aiming to increase the competitiveness of the sector on foreign markets and to enhance rural and environmental protection. Simultaneously, we have observed a marked growth of VWX to foreign European markets from 2007, mainly focused in Mediterranean countries that grow high valued and water-intensive products.

In this paper we focus on the analysis of the impact of the 2003 reform on extra EU VWX. In particular, we are interested in the variation in country pairs' water trade flows as a result of the decoupling of direct aids introduced by this important agricultural reform. In this regard, our methodology relies on a bottom-up approach which allows us to estimate European VWX using highly disaggregated data during the period from 1995 to 2013. We evaluate the impact of the policy reform using panel fixed regressions to address different forms of endogeneity associated to the standard trade gravity model.

Our main results, once we have considered the presence of omitted variable bias as well as the bias associated to unobservable bilateral trade costs and the potential selection of countries intro trade, indicate that the 2003 reform notably contributed to the increment of the total water embodied in extra EU exports. Besides, the fact that VWX increase substantially under the policy reform by country characteristics suggests the determinant role of specific EU countries, i.e., Mediterranean areas. The consideration of this heterogeneous effect is very important, especially when the economies of these countries are characterised by having a larger weight of agriculture in their GDP compared to their EU counterparts. Moreover, the agricultural sector of these Mediterranean countries is heavily oriented to international markets and based on high value-added agri-food products, which are mostly irrigated and therefore, highly intensive in the consumption of blue water. We have also seen that one country, Spain, is essential to understand the effect of decoupling on European VWX, posing serious questions on the water sustainability of the CAP during the last years.

From the policy-making viewpoint, the findings of this work seem rather paradoxical. On the one hand, the 2003 reform, seeking for the 
improvement of the sectoral competitiveness, but also, at least theoretically, for environmental protection, was triggering a higher consumption of water resources in the most arid areas of the EU. This result goes in line with Matthews (2013), who pointed at the failure of the CAP 2003 reform to promote environmental sustainability. On the other hand, the results indicate that the CAP has diverged from the WFD objectives, neglecting the opportunities highlighted by Heinz (2008) and leading to an insufficient integration of water management in the CAP (European Court of Auditors, 2014). Thus, our results call for a joint design of agricultural and water policies that guarantee the consistency of environmental and socio-economic objectives to further enhance agri-food systems sustainability in line with the coordination demanded by Gómez-Limón et al. (2002).

Moreover, the implementation of the most significant changes introduced by the 2013 reform, which replaced the SPS as the system of direct payments by including the basic payment scheme (BPS) as well as greening and redistributive payments among other forms of support targeting specific goals, has delivered insufficient modifications, and this is especially the case for Mediterranean countries. These particularly relevant member states in our study have adopted a model of support (i.e., partial convergence model) that in practice represents a minimum change with respect to the former 2003 reform (Henke et al., 2015). Thus, we consider it unlikely that the 2013 reform would alter the essence of our findings. Notwithstanding, the prompt availability of the relevant trade data would allow for a proper evaluation of the period 2013-2020.

Therefore, the post-2020 CAP scheme, which is currently under debate, should be designed on the basis of the available scientific empirical evidence on the social, economic and environmental effects of previous reforms in order to correctly address the challenges faced by the Sustainable Development Goals (SDGs). The European commitment on the SDGs should involve a decided support towards an agricultural policy in the framework of the European Green Deal and the Farm to Fork Strategy, where farming and food systems play a crucial role in the protection of natural resources and the reduction of environmental footprints. In this regard, the post-2020 CAP should promote the sustainability of the agri-food complex, striving for CAP funds that encourage the green transition, eventually moving away from the Business as Usual European agricultural model.

Finally, the results in this paper draw future research lines. First, it would be interesting to develop this analysis in a regional/local context, which would allow deepening into the heterogeneities seen at the country level and to evaluate the most affected areas -in terms of water resources-by the policy reform and its induced effects. Second, the impact of the CAP changes could also be assessed for different products, particularly focusing on water-intensive goods oriented to foreign markets. Finally, natural extensions of this study would be to investigate the relation between intra-EU trade and virtual water as well as to evaluate the effect of the reform not only focusing on trade data, but on the total production using a different methodological framework.

\section{Credit author statement}

Ana Serrano: Conceptualization, Methodology, Formal analysis, Writing - Original Draft, Writing - Review \& Editing. Javier Valbuena: Conceptualization, Methodology, Formal analysis, Writing - Original Draft, Writing - Review \& Editing.

\section{Declaration of competing interest}

The authors declare that they have no known competing financial interests or personal relationships that could have appeared to influence the work reported in this paper.

\section{Acknowledgements}

We would like to thank Andrea Tesei for helping us gathering the most recent data from United Nations Statistics Division. For useful comments we also thank the conference participants of the VIII Congress of the Sociedad de Estudios de Historia Agraria (SEHA) at Santiago de Compostela and XLIV Regional Studies Meeting at Valencia. This work has been partially supported by the Fundación Ramón Areces (Grant number CISP15A3198), Ministry of Science and Innovation of the Spanish Government (Grant number PID2019-106822RB-I00) and by the Department of Science, Technology and Universities of the Government of Aragon (Reference Groups S40_20R and S23_20R).

\section{Appendix A. Supplementary data}

Supplementary data to this article can be found online at https://doi. org/10.1016/j.jenvman.2020.111606.

\section{References}

Aichele, R., Felbermayr, G., 2015. Kyoto and carbon leakage: an empirical analysis of the carbon content of bilateral trade. Rev. Econ. Stat. 97, 104-115. https://doi.org/ 10.1162/REST_a_00438.

Allan, J.A., 1993. Fortunately There Are Substitutes for Water Otherwise Our Hydropolitical Futures Would Be Impossible, Priorities for Water Resources Allocation and Management. In: Overseas Development Administration, pp. 13-26. London, UK.

Allan, J.A., Hoekstra, A.Y., Chapagain, A.K., Aldaya, M.M., Mekonnen, M.M., Federico, G., Schandl, H., Schulz, N., 1997. 'Virtual water': a long term solution for water short middle eastern economies. Br. Assoc. Festiv. Sci. Univ. Leeds 9, 203-221. https://doi.org/10.1016/S0921-8009(02)00031-9.

Anderson, J.E., 1979. A theoretical foundation for the gravity equation. Am. Econ. Rev. 69, 106-116.

Anderson, J.E., van Wincoop, E., 2003. Gravity with gravitas: a solution to the border puzzle. Am. Econ. Rev. 93, 170-192.

Anderson, K., Valenzuela, E., 2008. Estimates of Global Distortions to Agricultural Incentives, 1955 to 2007. World Bank, Washingt. DC. https://doi.org/10.3386/ w12516.

Baier, S.L., Bergstrand, J.H., 2007. Do free trade agreements actually increase members' international trade? J. Int. Econ. 71, 72-95. https://doi.org/10.1016/j. jinteco.2006.02.005.

Baier, S.L., Bergstrand, J.H., 2004. Economic determinants of free trade agreements. J. Int. Econ. 64, 29-63. https://doi.org/10.1016/S0022-1996(03)00079-5.

Bergschmidt, A., Nitsch, H., Osterburg, B., 2003. Good Farming Practice - Definitions, Implementation, Experiences. Report on the results of work package 2 within the EU Concerted Action. Developing cross-compliance in the EU - background, lessons and opportunities, Braunschweig.

Bergstrand, J.H., 1989. The generalized gravity equation, monopolistic competition, and the factor-proportions theory in international trade. Rev. Econ. Stat. 71, 143-153. https://doi.org/10.2307/1928061.

Bergstrand, J.H., 1985. The gravity equation in international trade: some microeconomic foundations and empirical evidence. Rev. Econ. Stat. 67, 474-481. https://doi.org/ $10.2307 / 1925976$.

Bergstrand, J.H., Larch, M., Yotov, Y.V., 2015. Economic integration agreements, border effects, and distance elasticities in the gravity equation. Eur. Econ. Rev. 78, 307-327. https://doi.org/10.1016/j.euroecorev.2015.06.003.

Beverelli, C., Keck, A., Larch, M., Yotov, Y.V., 2018. Institutions, Trade and Development: A Quantitative Analysis (No. 6920). CESifo Working Paper Series, Munich.

Brady, M., Kellermann, K., Sahrbacher, C., Jelinek, L., 2009. Impacts of decoupled agricultural support on farm structure, biodiversity and landscape mosaic: some EU results. J. Agric. Econ. 60, 563-585. https://doi.org/10.1111/j.1477 9552.2009.00216.x.

Byerlee, D., de Janvry, A., Sadoulet, E., 2011. Agriculture for Development: toward a New Paradigm. SSRN. https://doi.org/10.1146/annurev.resource.050708.144239.

Carr, J.A., D'Odorico, P., Laio, F., Ridolfi, L., 2013. Recent history and geography of virtual water trade. PloS One 8, e55825. https://doi.org/10.1371/journal. pone.0055825.

Cazcarro, I., Duarte, R., Martín-Retortillo, M., Pinilla, V., Serrano, A., 2015. How sustainable is the increase in the water footprint of the Spanish agricultural sector? A provincial analysis between 1955 and 2005-2010. Sustainability 7, 5094-5119. https://doi.org/10.3390/su7055094.

Cazcarro, I., Martín-Retortillo, M., Serrano, A., 2019. Reallocating regional water apparent productivity in the long term: methodological contributions and application for Spain. Reg. Environ. Change 19, 1455-1468. https://doi.org/ 10.1007/s10113-019-01485-9.

Chico, D., Garrido, A., 2012. Overview of the extended water footprint in Spain: the importance of agricultural water consumption in the Spanish economy. In: Stefano, L. De, Llamas, M.R. (Eds.), Water, Agriculture and the Environment in Spain: Can We Square the Circle? - Contents. Taylor \& Francis Group, London, UK. 
Coderoni, S., Esposti, R., 2018. CAP payments and agricultural GHG emissions in Italy. A farm-level assessment. Sci. Total Environ. 627, 427-437. https://doi.org/10.1016/J. SCITOTENV.2018.01.197.

Collantes, F., 2020. The Political Economy of the Common Agricultural Policy: Coordinated Capitalism or Bureaucratic Monster? Routledge.

De Graaff, J., Kessler, A., Duarte, F., 2011. Financial consequences of cross-compliance and flat-rate-per-ha subsidies: the case of olive farmers on sloping land. Land Use Policy. https://doi.org/10.1016/j.landusepol.2010.08.001.

Dos Santos, M.J.P., Henriques, P.D., Fragoso, R.E., Da Silva Carvalho, M.L., 2010. Attitudes of the Portuguese farmers to the EU common agricultural policy. Agric. Econ. 56, 460-469.

Duarte, R., Pinilla, V., Serrano, A., 2019. Long term drivers of global virtual water trade: a trade gravity approach for 1965-2010. Ecol. Econ. 156, 318-326. https://doi.org/ 10.1016/J.ECOLECON.2018.10.012.

Duarte, R., Pinilla, V., Serrano, A., 2018. Factors driving embodied carbon in international trade: a multiregional input-output gravity model. Econ. Syst. Res. 30, 545-566. https://doi.org/10.1080/09535314.2018.1450226.

Duarte, R., Pinilla, V., Serrano, A., 2016. Globalization and natural resources: the expansion of the Spanish agrifood trade and its impact on water consumption, 1965-2010. Reg. Environ. Change 16, 259-272. https://doi.org/10.1007/s10113014-0752-3.

Eaton, J., Kortum, S., 2002. Technology, geography, and trade. Econometrica 70, 1741-1779. https://doi.org/10.1111/1468-0262.00352.

Egger, P., Nelson, D., 2011. How bad is antidumping? Evidence from panel data. Rev. Econ. Stat. 93, 1374-1390. https://doi.org/10.1162/REST_a_00132.

Egger, P.H., Nigai, S., 2015. Structural gravity with dummies only: constrained ANOVAtype estimation of gravity models. J. Int. Econ. 97, 86-99. https://doi.org/10.1016/ j.jinteco.2015.05.004.

European Commission, 2018. Proposal for a Regulation of the European Parliament and of the Council Establishing Rules on Support for Strategic Plans to Be Drawn up by Member States under the Common Agricultural Policy (CAP Strategic Plans) and Financed by the European Agricultural.

European Commission, 2016. Agri-food Trade in 2015. Monitoring Agri-food policy.

European Commission, 2007. The Changing Face of EU Agricultural Trade. Monitoring Agri-Trade Policy.

European Commission, 2000. Directive 2000/60/EC of the European Parliament and of the Council of 23 October 2000 Establishing a Framework for Community Action in the Field of Water Policy.

European Commission, 1999. Council Regulation $1259 / 1999$ of 17 May 1999 Establishing Common Rules for Direct Support Schemes under the Common Agricultural Policy (Belgium).

European Court of Auditors, 2014. Integration of EU Water Policy Objectives with the CAP: a Partial Success (Brussels).

European Environment Agency, 2018. Use of Freshwater Resources [WWW Document] URL https://www.eea.europa.eu/data-and-maps/indicators/use-of-freshwater-resou rces-2/assessment-2.

EUROSTAT, 2018. Extra-EU Trade in Agricultural Goods [WWW Document]. Stat. Explain. URL. https://ec.europa.eu/eurostat/statistics-explained/index.php/Extra EU_trade_in_agricultural_goods.

Farm Accountancy Data Network, 2018. Farm Accountancy Data Network - FADN Public Database.

Flávio, H.M., Ferreira, P., Formigo, N., Svendsen, J.C., 2017. Reconciling agriculture and stream restoration in Europe: a review relating to the EU Water Framework Directive. Sci. Total Environ. 596-597, 378-395. https://doi.org/10.1016/J. SCITOTENV.2017.04.057.

Frankel, J.A., Rose, A.K., 2005. Is trade good or bad for the environment? Sorting out the causality. Rev. Econ. Stat. 87, 85-91. https://doi.org/10.1162/0034653053327577.

Garrido, A., Llamas, M.R., Varela-Ortega, C., Novo, P., Rodríguez-Casado, R., Aldaya, M. M., 2010. Water Footprint and Virtual Water Trade in Spain: Policy Implications, Natural Resource Management and Policy. Springer- Fundación Marcelino Botín.

Garrido, A., Varela-Ortega, C., 2008. Economía del agua en la agricultura e integración de políticas sectoriales. Water Economics in Agriculture and Integration of Sectoral Policies.

Giannoccaro, G., Berbel, J., 2011. Influence of the Common Agricultural Policy on the farmer's intended decision on water use. Spanish J. Agric. Res. 9, 1021-1034.

Gómez-Limón, J.A., Arriaza, M., Berbel, J., 2002. Conflicting implementation of agricultural and water policies in irrigated areas in the EU. J. Agric. Econ. 53, 259-281. https://doi.org/10.1111/j.1477-9552.2002.tb00020.x.

Head, K., Mayer, T., 2015. Gravity equations: workhorse,Toolkit, and cookbook. In: Gopinath, G., Helpman, E., Rogoff, K. (Eds.), Handbook of International Economics. Elsevier, Amsterdam, pp. 131-195. https://doi.org/10.1016/B978-0-444-54314 1.00003-3.

Head, K., Mayer, T., 2014. Gravity equations: workhorse, toolkit, and cookbook. In: Gopinath, G., Helpman, E., Rogoff, K. (Eds.), Handbook of International Economics. Elsevier, Amsterdam.

Head, K., Mayer, T., Ries, J., 2010. The erosion of colonial trade linkages after independence. J. Int. Econ. 81, 1-14. https://doi.org/10.1016/j. jinteco.2010.01.002

Heid, B., Larch, M., Yoto, Y.V., 2017. Estimating the Effects of Non-discriminatory Trade Policies within Structural Gravity Models (No. 6735). CESifo Working Paper Series, Munich.

Heinz, I., 2008. Co-operative agreements and the EU water framework directive in conjunction with the common agricultural policy. Hydrol. Earth Syst. Sci. 12, 715-726. https://doi.org/10.5194/hess-12-715-2008.
Henke, R., D’Andrea, M.R.P., Benos, T., Castellotti, T., Pierangeli, F., Lironcurti, S., De Filippis, F., Giua, M., Rosatelli, L., Resl, T., 2015. Implementation of the First Pillar of the CAP 2014-2020 in the EU Member States. Eur. Union, July.

Hoekstra, A.Y., Chapagain, A.K., Aldaya, M.M., Mekonnen, M.M., 2011. The Water Footprint Assessment Manual: Setting the Global Standard. Earthscan, London, UK.

Hoekstra, A.Y., Hung, P.Q., 2005. Globalisation of water resources: international virtual water flows in relation to crop trade. Global Environ. Change 15, 45-56. https://doi. org/10.1016/j.gloenvcha.2004.06.004.

Hoekstra, A.Y., Mekonnen, M.M., 2012. The water footprint of humanity. Proc. Natl. Acad. Sci. U.S.A. 109, 3232-3237.

Jaime, M.M., Coria, J., Liu, X., 2016. Interactions between CAP agricultural and agrienvironmental subsidies and their effects on the uptake of organic farming. Am. J. Agric. Econ. 98, 1114-1145.

Jaraitè, J., Kažukauskas, A., 2012. The effect of mandatory agro-environmental policy on farm fertiliser and pesticide expenditure. J. Agric. Econ. 63, 656-676. https://doi org/10.1111/j.1477-9552 2012.00346.x.

Kampas, A., Petsakos, A., Rozakis, S., 2012. Price induced irrigation water saving unraveling conflicts and synergies between European agricultural and water policies for a Greek Water District. Agric. Syst. 113, 28-38. https://doi.org/10.1016/J. AGSY.2012.07.003.

Llamas, M.R., Stefano, L. De, Aldaya, M., Custodio, E., Garrido, A., López-Gunn, E., Willaarts, B., 2012. Introduction. In: Stefano, Lucia De, Ramón, Llamas M. (Eds.), Water, Agriculture and the Environment in Spain: Can We Square the Circle? Contents. Taylor \& Francis Group, London, UK.

MAPA, 2013. Encuesta sobre Superficies y Rendimientos de Cultivos (ESYRCE). Informe sobre los regadíos en España.

MAPA, 2008. Encuesta sobre Superficies y Rendimientos de Cultivos (ESYRCE). Informe sobre los regadíos en España.

Martín-Retortillo, M., Serrano, A., Cazcarro, I., 2020. Double concentration explaining the outstanding increase in the Spanish agricultural production. Spanish J. Agric. Res. 18 https://doi.org/10.5424/sjar/2020183-15760.

Matthews, A., 2013. Greening agricultural payments in the EU's common agricultural policy. Bio base Appl. Econ. https://doi.org/10.13128/BAE-12179.

Matthews, A., Salvatici, L., Scoppola, M., 2017. Trade impacts of agricultural support in the EU, commissioned papers. In: International Agricultural Trade Research Consortium.

Matthews, A., Soldi, R., 2019. Evaluation of the Impact of the Current CAP on the Agriculture of Developing Countries Matthews 2019. European Committee of the Regions. https://doi.org/10.2863/81237.

Mayer, T., Zignago, S., 2011. Notes on CEPII's distances measures: the GeoDist database. SSRN Electron. J. 25 https://doi.org/10.2139/ssrn.1994531.

Mekonnen, M., Hoekstra, A., 2011. The green, blue and grey water footprint of crops and derived crop products. Hydrol. Earth Syst. Sci. 15, 1577-1600.

Mekonnen, M., Hoekstra, A.Y., 2012. A global assessment of the water footprint of farm animal products. Ecosystems 1-15.

Okman, L., Gal-Oz, N., Gonen, Y., Gudes, E., Abramov, J., 2011. Security issues in NoSQL databases. In: Proc. 10th IEEE Int. Conf. on Trust, Security and Privacy in Computing and Communications, TrustCom 2011, 8th IEEE Int. Conf. on Embedded Software and Systems, ICESS 2011. 6th Int. Conf. on FCST, pp. 541-547. https://doi.org/ 10.1109/TrustCom.2011.70.

Phelps, J., 2007. Much ado about decoupling: evaluating the environmental impact of recent European Union agricultural reform. Harv. Environ. Law Rev. https://doi. org/10.1016/0146-6402(89)90027-1.

Ruiz, J., Bardají, I., Garrido, A., Iglesias, E., 2011. Impacto de la reforma de la PAC 2003 sobre la agricultura española [Impact of the 2003 CAP reform over Spanish Agricultural production]. In: Asociación Española de Economía Agraria (AEEA). VIII Congreso de Economía Agraria: El Sistema Agroalimentario y El Mundo Rural En Una Economía Innovadora y Sostenible. Asociación Española de Economía Agraria (AEEA), Madrid, Spain.

Santos-Silva, J.M.C., Tenreyro, S., 2010. On the existence of the maximum likelihood estimates in Poisson regression. Econ. Lett. 107, 310-312. https://doi.org/10.1016/ j.econlet.2010.02.020.

Santos-Silva, J.M.C., Tenreyro, S., 2006. The log of gravity. Rev. Econ. Stat. 88, 641-658. https://doi.org/10.1162/rest.88.4.641.

Scardigno, A., Viaggi, D., 2007. The impacts of the 2003 CAP reform on water demand for irrigation in the european mediterranean countries. In: 3rd Regional Workshop on Water and Sustainable Development in the Mediterranean. UNEP/MAP/BLUE PLAN, Zaragoza.

Scheidel, A., Krausmann, F., 2011. Diet, trade and land use: a socio-ecological analysis of the transformation of the olive oil system. Land Use Pol. https://doi.org/10.1016/j. landusepol.2010.04.008.

Schmitz, C., Biewald, A., Lotze-Campen, H., Popp, A., Dietrich, J.P., Bodirsky, B. Krause, M., Weindl, I., 2012. Trading more food: implications for land use, greenhouse gas emissions, and the food system. Global Environ. Change 22, 189-209. https://doi.org/10.1016/j.gloenvcha.2011.09.013.

Serrano, A., Guan, D., Duarte, R., Paavola, J., 2016. Virtual water flows in the EU27: a consumption-based approach. J. Ind. Ecol. 20, 547-558.

Stoate, C., Báldi, A., Beja, P., Boatman, N.D., Herzon, I., van Doorn, A., de Snoo, G.R., Rakosy, L., Ramwell, C., 2009. Ecological impacts of early 21st century agricultural change in Europe - a review. J. Environ. Manag. 91, 22-46. https://doi.org/ 10.1016/J.JENVMAN.2009.07.005.

Tinbergen, J., 1962. Shaping the World Economy; Suggestions for an International Economic Policy. Twentieth Century Fund, New York, US.

Tuninetti, M., Tamea, S., Laio, F., Ridolfi, L., 2016. To trade or not to trade: link prediction in the virtual water network. Adv. Water Resour. https://doi.org/ 10.1016/j.advwatres.2016.08.013. 
United Nations, 2019. UN Comtrade Database.

Volkov, A., Melnikiene, R., 2017. CAP direct payments system's linkage with environmental sustainability indicators. Public Policy Adm. https://doi.org/ 10.13165/VPA-17-16-2-05.

Vörösmarty, C.J., Hoekstra, A.Y., Bunn, S.E., Conway, D., Gupta, J., 2015. Fresh water goes global. Science 349, 478 LP - 479.

World Bank, 2019. World Development Indicators.
Yotov, Y.V., Piermartini, R., Monteiro, J.-A., Larch, M., 2016. An Advanced Guide to Trade Policy Analysis: the Structural Gravity Model. WTO and UN, Geneva, Switzerland.

Zhao, X., Liu, J., Liu, Q., Tillotson, M.R., Guan, D., Hubacek, K., 2015. Physical and virtual water transfers for regional water stress alleviation in China. Proc. Natl. Acad. Sci. Unit. States Am. 112, 1031 LP - 1035. 